\title{
Factors Affecting Customers Brand Switching Behavior in Mobile Telecommunication Industry: A Study of Pabna District in Bangladesh
}

\author{
Md. Masud-Ul-Hasan* \\ Assistant Professor, Department of Business Administration, Pabna University of Science and Technology, Pabna, BANGLADESH \\ *E-mail for correspondence: mhasan.mkt.ru@gmail.com
}

DOI: https://doi.org/10.18034/abr.v6i3.37

\begin{abstract}
The mobile telecommunication market in Bangladesh has already been saturated. In this matured market every company wants to protect their customer from being switched to their competitors. On the other hand, every company tries to attract the competitor's customer. In this situation it is very important to understand every detail of the customers switching behavior. This study was intended to identify the factors affecting brand switching behavior as well as the factors which create the switching barrier.
\end{abstract}

Keywords: Mobile telecommunication industry, Customer loyalty, switching behavior, switching barrier

\section{INTRODUCTION}

In Bangladesh mobile telecommunication service was introduced in 1989 when Sheba Telecom got a license to operate exchange is 199 upazilla (An upazilla is a geographical region in Bangladesh used for administrative or other purposes. They function as sub-units of districts). In the same year, mobile phone Company Pacific Bangladesh Telephone Limited (City cell) and Bangladesh Telecom got a license. In 1996 Grameen Phone and Telecom Malaysia International Bangladesh (Robi) got cellular mobile Telephone license. The first government-owned mobile operator Teletalk mobile launched in 2004(Source: Wikipedia). Currently, the mobile telecommunication industry in Bangladesh is composed of five companies. These are Grameen Phone Ltd. (GP); Orascom Telecom Bangladesh Limited (Banglalink); Robi Axiata Limited (Robi); Airtel Bangladesh Limited (Airtel); Pacific Bangladesh Telecom Limited (Citycell) and Teletalk Bangladesh Ltd. (Teletalk).Among the five companies the first four are privately owned, and the fifth one is stateowned. 3G mobile service was introduced in Bangladesh by the state-owned Teletalk in October 2012. In 2014, all 64 districts covered with 3G by Grameen Phone, Banglalink, and Robi. A total number of mobile telecommunication service users have reached 128.939 million at the end of July 2016 compared to 128.769 at this time of 2015 and 116.871 in 2014 (Source: BTRC). The trend shows that the growth rate of mobile telecommunication service is decreasing. Evidence indicates that the mobile telecommunication market in Bangladesh has saturated. In this saturated and matured market every company intend togives their best effort to keep their customer loyal over this fierce competition. As the primary demand has reached its destiny, most companies try to keep their customer loyal and then design marketing strategies to switch competitor's customer. In this context academicians and marketing practitioners find interest in conducting research on customer's switching behavior. In this paper researcher intended to identify the factors affecting customers switching behavior and factors create the switching barrier in mobile telecommunication industry of Bangladesh. The study was conducted in Pabna district of Bangladesh.

\section{ObJectives OF the Study}

The study was accomplished to serve the following objectives:

- To identify nature of the mobile telecommunication service users in Pabna.

- To understand the demographic information of the mobile telecommunication service user in Pabna.

- To identify the factors affecting switching behavior of mobile telecommunication service user in Pabna.

- To identify the factors creating the switching barrier of the mobile telecommunication service user in Pabna. 


\section{MetHodologY}

The study was quantitative in nature. The research has been conducted based on both primary and secondary data. To identify the factors affecting customers brand switching behavior a pre-questionnaire survey on 20 numbers of university level students; 5 service holders; 5 business person and two retired person has been conducted. And at the same time, some previous literature has been reviewed as well as in-depth interview with customer care manager has been taken. By pre-questionnaire survey as well as literature review and an in-depth interview some 12 factors under the headline of price, inconvenience, and service failure were identified. At the same time, some 4 factors which act as a switching barrier were also identified. By those factors, a full-length questionnaire was prepared. The questionnaire was divided into three parts. In the first, respondent's demographic factors like age, sex, marital status, education level and other uses related questions were incorporated. In the second parts, respondents were asked about the previously identified factors affecting customers switching behavior. And in the third parts, respondents were asked about the switching barrier factors. Both open ended and close ended question were used in the preparing questionnaire. In close ended questions, a four-point Likert scale was used for the purpose of ease of analysis. Finally some 200 respondents of whom 104 were students, 52 were service holders, 38 were businessperson, and 6 were retired person interviewed in Pabna, Bangladesh by the questionnaire. The collected data was analyzed and presented by using basic statistical tools like percentage.

\section{LITERATURE REVIEW}

According to Fornell \& Wernerfelt (1987) and Zeithaml (2000), A decrease in customer switching creates benefits on both sides of the income statement in the form of higher revenues and lower costs and has been shown to be effective from both defensive and offensive strategic marketing perspectives.

Keaveney, S. M. (1995) identified seven factors which affect customer's service switching behavior in his model of customer's service switching behavior. Among those seven factors he gave priority upon price, inconvenience, and core service failure factor.

Porter M (1998) in his book Competitive Strategy: Techniques for Analyzing Industries and Competitors define Switching cost which is also known as switching barrier as the cost that incurs when a consumer change one service provider to another service provider.

Jackson (1985) define it is the sum of economic, psychological and physical costs.

Kollmann (2000) concludes that price is an important factor in the mobile telecommunication service industry. Price includes purchasing price, call rate, SMS rate, etc.
Jones, Mothersbaugh, \& Betty (2002), commented that not only customer satisfaction and customer loyalty is a potentially important factors but also the concept of switching barrier is a potentially influential factors that should be analyzed.

Colgate \& Lang (2001); Jones et al., (2002); Lee \& Cunningham (2001), asserted that switching barrier plays the role of an adjustment variable in the interrelationship between customer satisfaction and customer loyalty. That means when the level of customer satisfaction is identical, the level of customer loyalty can be different depending on the magnitude of the switching barrier.

Fornell(1992) and Ahmad \&Buttle (2002), identifies the significance of customer loyalty as it closely relates to the company's continued survival, and future growth. Thus when, a company, reached its total potential customer, when the market is saturated, the market is matured, when there is a cut throat competition- a defensive strategy is the best to retain the existing customers than the acquiring new customer by taking more aggressive strategy to expand the primary demand by finding potentially new customer.

\section{FINDINGS}

\section{Demographic finding:}

Among the total 200 number of respondents 120 were male and 80 were female. The age range of respondents consisted of $16 \%$ below 20 years, $48 \%$ is of $20-30$ years; $32 \%$ is $31-49$ years of age and rest $4 \%$ of the respondents were above 50 years old. Among the respondents $52 \%$ were student; $26 \%$ were service holder; $19 \%$ were businessman; and 3\% of were senior retired person. 52\% of the respondents were married, and $48 \%$ of the respondents were unmarried. The education level is $6 \%$ below SSC;12\% SSC;32\% HSC; $28 \%$ bachelor and 22\% were masters and above. Among the respondent's 55\% use Grameen phone; $18 \%$ use Banglalink; $15 \%$ use Robi; $6 \%$ use Teletalk; $5 \%$ Airtel and rest $1 \%$ use City cell brand as their first choice. Most of the $(96 \%)$ of the total respondent have more than one SIM card of different operator.The cent percent of the respondent's first purpose of using telecom service is voice mail; $60 \%$ respondent's second purpose of using telecom service is mobile internet; $25 \%$ second purpose of using telecom service is using SMS service and rest 15\% has any choice other than using VMS.32\% respondents use below 300 Taka per month; 30\% respondents use Taka 300 to 500 per month; $34 \%$ respondents use Taka 501 to 700 and rest $4 \%$ use more than 700 Taka per month.

\section{Factors affecting customers brand switching behavior:}

By the help of a pre-questionnaire survey on 20 numbers of university level students; 5 service holders; 5 businessperson and two retired person, and on the basis of previous literature review as well as in-depth interview with customer care manager the following 
factors were identified as a motivators of customers brand switching and factors that create barriers to brand switching. (Table: 1 and Table: 2)

Table 1: Factors affecting customers brand switching in mobile telecommunication industry

\begin{tabular}{|l|l|}
\hline & \multicolumn{1}{|c|}{ Price } \\
\cline { 2 - 3 } & - Per minute Voice call rate \\
& - Per minute video call rate
\end{tabular}

Table 2: Factors creating barriers to customers brand switching in mobile telecommunication industry

Factors creating barriers to customers brand switching in mobile telecommunication industry

- As there is no option to buy other operators service with the same mobile number.(The service is also known as Mobile Number Portability- MNP)

- As most of the friends and family member use a same mobile operator's brand

- As still in some places where there is no network coverage of every operator

- As customers are loyal to brand

Price-related factors affecting customers brand switching behavior:

When respondents are asked whether they will switch other operators or not due to the high rate of per minute voice call, $30 \%$ of the total respondents strongly agreed that they will; $45 \%$ agreed they will; $20 \%$ disagreed and $5 \%$ of the respondents strongly disagreed that they $\mathrm{r}$ will switch to other operators brand.

When respondents are asked whether they will or would switch other operators or not due to the high rate of per minute video call, $16 \%$ of the total respondents strongly agreed that they will; $44 \%$ agreed they will; $32 \%$ disagreed and $8 \%$ of the respondents strongly disagreed that they will switch to other operators brand.

When respondents are asked whether they will switch other operators or not due to the high rate of $3 G$ or mobile internet, $28 \%$ of the total respondents strongly agreed that they will; $52 \%$ agreed they will; $16 \%$ disagreed and $4 \%$ of the respondents strongly disagreed that they will switch to other operators brand.
When respondents are asked whether they will switch other operators or not due to the high rate of SMS, $16 \%$ of the total respondents strongly agreed that they will switch; $38 \%$ agreed they will; $32 \%$ disagreed and $14 \%$ of the respondents strongly disagreed that they will switch to other operators brand.

Finally, it is found that $67.25 \%$ of the total respondents think they will switch to other operators brand considering the price factors.

Table 3: Price-related factors affecting customers brand switching behavior

\begin{tabular}{|c|c|c|c|c|c|}
\hline \multirow{2}{*}{\multicolumn{2}{|c|}{ br }} & \multicolumn{4}{|c|}{ nd switching } \\
\hline & & 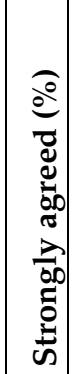 & 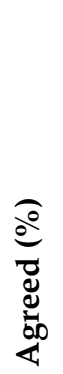 & 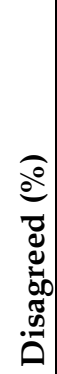 & 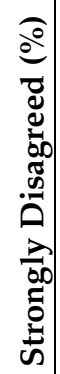 \\
\hline 01 & $\begin{array}{l}\text { Per minute voice call rate is an } \\
\text { important factor in switching to } \\
\text { other mobile operators brand }\end{array}$ & 30 & 45 & 20 & 5 \\
\hline 02 & $\begin{array}{l}\text { Per minute video call rate is an } \\
\text { important factor in switching to } \\
\text { other mobile operators brand }\end{array}$ & 16 & 44 & 32 & 8 \\
\hline 03 & $\begin{array}{l}\text { 3G internet or mobile internet } \\
\text { rate is an important factor in } \\
\text { switching to other mobile } \\
\text { operators brand }\end{array}$ & 28 & 52 & 16 & 4 \\
\hline 04 & $\begin{array}{l}\text { SMS rate is an important factor } \\
\text { in switching to other mobile } \\
\text { operators brand }\end{array}$ & 16 & 38 & 32 & 14 \\
\hline & Total & 22.5 & 44.75 & 25 & 7.75 \\
\hline
\end{tabular}

Inconvenience related factors affecting customers brand switching behavior:

When respondents are asked whether they will switch other operators or not due to the late response of operator, $27 \%$ of the total respondents strongly agreed that they will switch; $43 \%$ agreed they will; $25 \%$ disagreed and $5 \%$ of the respondents strongly disagreed that they will switch to other operators brand.

When respondents are asked whether they will switch other operators or not due to late activation of packages, $30 \%$ of the total respondents strongly agreed that they will switch; $48 \%$ agreed they will; $20 \%$ disagreed and $2 \%$ of the respondents strongly disagreed that will switch to other operators brand.

When respondents are asked whether they will switch other operators or not due to no updates on package activation, $18 \%$ of the total respondents strongly agreed 
that they will switch; $32 \%$ agreed they will; $32 \%$ disagreed and $18 \%$ of the respondents strongly disagreed that they will switch to other operators brand.

When respondents are asked whether they will switch other operators or not due to late delivery of SMS, $25 \%$ of the total respondents strongly agreed that they will switch; $61 \%$ agreed they will; $12 \%$ disagreed and $2 \%$ of the respondents strongly disagreed that they will switch to other operators brand.

Finally, it is found that $71 \%$ of the total respondents think they will switch to other operators brand considering the inconvenience factors.

Table 4: Inconvenience related factors affecting customers brand switching behavior

\begin{tabular}{|c|c|c|c|c|c|}
\hline \multicolumn{6}{|c|}{$\begin{array}{l}\text { How Inconvenience affects customers brand } \\
\text { switching behavior }\end{array}$} \\
\hline & & \multirow[t]{2}{*}{ 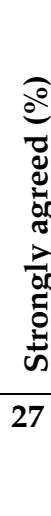 } & \multirow{2}{*}{ 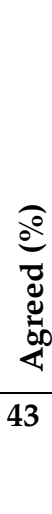 } & \multirow[t]{2}{*}{ 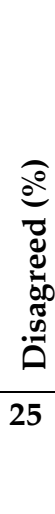 } & \multirow[t]{2}{*}{ 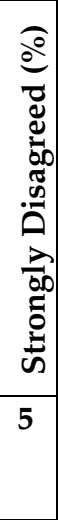 } \\
\hline 01 & $\begin{array}{l}\text { Late response of operator is an } \\
\text { important factor in switching to } \\
\text { other mobile operators brand }\end{array}$ & & & & \\
\hline 02 & $\begin{array}{l}\text { Late activation of packages is an } \\
\text { important factor in switching to } \\
\text { other mobile operators brand }\end{array}$ & 30 & 48 & 20 & 2 \\
\hline 03 & $\begin{array}{l}\text { No updates on package } \\
\text { activation is an important factor } \\
\text { in switching to other mobile } \\
\text { operators brand }\end{array}$ & 18 & 32 & 32 & 18 \\
\hline 04 & $\begin{array}{l}\text { Late delivery of SMSis an } \\
\text { important factor in switching to } \\
\text { other mobile operators brand }\end{array}$ & 25 & 61 & 12 & 2 \\
\hline & Total & 25 & 46 & $\begin{array}{c}22.2 \\
5\end{array}$ & 6.75 \\
\hline
\end{tabular}

Service failure related factors affecting customers brand switching behavior:

When respondents are asked whether they will switch other operators or not due to Signal dropping, 30\% of the total respondents strongly agreed that they will switch; $48 \%$ agreed they will; $18 \%$ disagreed and $4 \%$ of the respondents strongly disagreed that they will switch to other operators brand.

When respondents are asked whether they will switch other operators or not due distortion of calls, $26 \%$ of the total respondents strongly agreed that they will switch; $48 \%$ agreed they will; $20 \%$ disagreed and $6 \%$ of the respondents strongly disagreed that they will switch to other operators brand.
When respondents are asked whether they will switch other operators or not due to cross connection problem, $32 \%$ of the total respondents strongly agreed that they will switch; $42 \%$ agreed they will; $16 \%$ disagreed and $10 \%$ of the respondents strongly disagreed that they will switch to other operators brand.

When respondents are asked whether they will switch other operators or not due to low speed of $3 \mathrm{G}$ or mobile internet, $22 \%$ of the total respondents strongly agreed that they will switch; $46 \%$ agreed they will; $18 \%$ disagreed and $14 \%$ of the respondents strongly disagreed that they will switch to other operators brand.

Finally, it is found that $73.5 \%$ of the total respondents think they will switch to other operators brand considering the service failure factors.

Table 5: Service failure related factors affecting customers brand switching behavior

\begin{tabular}{|c|c|c|c|c|c|}
\hline \multicolumn{6}{|c|}{ How Service failure affects customers brand } \\
\hline & & 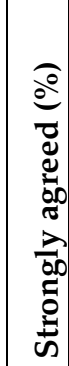 & 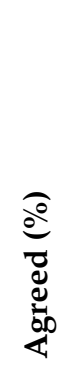 & 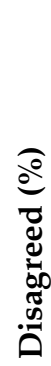 & 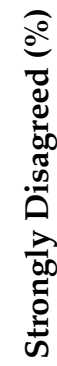 \\
\hline 01 & $\begin{array}{l}\text { Signal dropping is an important } \\
\text { factor in switching to other mobile } \\
\text { operators brand }\end{array}$ & 30 & 48 & 18 & 4 \\
\hline 02 & $\begin{array}{l}\text { Distortion of calls is an important } \\
\text { factor in switching to other mobile } \\
\text { operators brand }\end{array}$ & 26 & 48 & 20 & 6 \\
\hline 03 & $\begin{array}{l}\text { Cross connection problem is an } \\
\text { important factor in switching to } \\
\text { other mobile operators brand }\end{array}$ & 32 & 42 & 16 & 10 \\
\hline 04 & $\begin{array}{l}\text { Low speed of } 3 G \text { or mobile } \\
\text { internet isan important factor in } \\
\text { switching to other mobile } \\
\text { operators brand }\end{array}$ & 22 & 46 & 18 & 14 \\
\hline & Total & 27.5 & 46 & 18 & 8.5 \\
\hline
\end{tabular}

Factors creating barriers to customers brand switching:

As there is no way to keep the existing mobile number in another operator's brand and that's why $16 \%$ of the total respondents strongly agreed this as a switching barrier; $42 \%$ agreed; $32 \%$ disagreed and $10 \%$ of the respondents strongly disagreed this situation as a switching barrier.

As most of the friends and family member use a same mobile operator's brand that's why $32 \%$ of the total respondents strongly agreed this as a switching barrier; $46 \%$ agreed; $12 \%$ disagreed and $10 \%$ of the respondents strongly disagreed this situation as a switching barrier. 
As still in some places where there is no network coverage of every operator that's why $15 \%$ of the total respondents strongly agreed this as a switching barrier; $36 \%$ agreed; $36 \%$ disagreed and $13 \%$ of the respondents strongly disagreed with this situation as a switching barrier.

$21 \%$ of the total respondents strongly agreed that brand loyalty is an important switching barrier where $52 \%$ of the total respondents agreed that brand loyalty is an important switching barrier and rest 27 do not think brand loyalty as switching barrier.

Table 6: Factors creating barriers to customers brand switching

\begin{tabular}{|c|c|c|c|c|c|}
\hline & & & \\
\hline & & & & \multicolumn{2}{|c|}{ 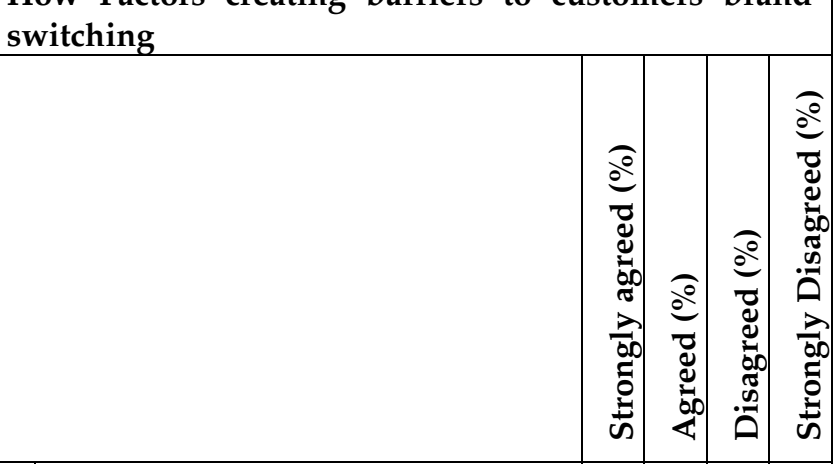 } \\
\hline \multicolumn{6}{|c|}{\begin{tabular}{|l|l|l|l|l|l}
01 & As there is no option to buy other & $\mathbf{1 6}$ & $\mathbf{4 2}$ & $\mathbf{3 2}$ & $\mathbf{1 0}$
\end{tabular}} \\
\hline 02 & $\begin{array}{l}\text { As most of the friends and family } \\
\text { member use a same mobile } \\
\text { operator's brand }\end{array}$ & 32 & 46 & 12 & 10 \\
\hline 03 & $\begin{array}{l}\text { As still in some places where there } \\
\text { is no network coverage of every } \\
\text { operator }\end{array}$ & 15 & 36 & 36 & 13 \\
\hline \multirow[t]{2}{*}{04} & As customers are loyal to brand & 21 & 52 & 14 & \\
\hline & & 21 & & \multicolumn{2}{|c|}{23.511 .5} \\
\hline
\end{tabular}

\section{Conclusions}

Evidence shows that price, inconvenience, and service failure are important factors that affect the consumers brand switching behavior. Among these three factors, consumers are more affected firstly by service failure and then inconvenience, and lastly price. So it can be concluded that if consumer finds the best service quality conveniently, they would be less price sensitive and be loyal. At the same time although the customers are less sensitive to the price of the three factors but the company should not charge very high price than their competitors. Among the four switching barrier, companies should emphasize on creating a friends and family circle with same operators by providing various facilities and making customers loyal to the brand as the benefits of those two factors will last longer and never be obsolete. But the other two factors, no option to keep the existing mobile number in other operator known-MNP and insufficient or no network coverage of competitors, cannot work as switching barrier for long-run basis as the government may introduce or force the operators to introduce MNP facility, and the competitors may be capable of establishing or expanding their network coverage, thus the switching barrier based on said two factors may be obsolete.

\section{REFERENCE}

Ahmad, R., \& Buttle, F. (2002). Customer retention management: A reflection of theory and practice. Marketing Intelligence \& Planning, 20(3), 149-161.

Colgate, M., \& Lang, B. (2001). Switching barriers in consumer markets: an investigation of the financial services industry. Journal of consumer marketing, 18(4), 332-347

Fornell, C. (1992). A national customer satisfaction barometer: The Swedish experience. the Journal of Marketing, 6-21

Fornell, C., \& Wernerfelt, B. (1987). Defensive marketing strategy by customer complaint management: a theoretical analysis. Journal of Marketing research, 337-346

Jackson, B.B. 1985, Winning and Keeping Industrial Customers, Lexington Books, Lexington, MA

Jones, M. A., Mothersbaugh, D. L., \& Beatty, S. E. (2000). Switching barriers and repurchase intentions in services. Journal of retailing, 76(2), 259-274

Jones, M. A., Mothersbaugh, D. L., \& Beatty, S. E. (2002). Why customers stay: measuring the underlying dimensions of services switching costs and managing their differential strategic outcomes. Journal of business research, 55(6), 441-450

Keaveney, S. M. (1995). Customer switching behavior in service industries: An exploratory study. The Journal of Marketing, 71-82

Kollmann, T. (2000). The price/acceptance function: perspectives of a pricing policy in European telecommunication markets. European Journal of Innovation Management, 3(1), 7-15

Lee, M., \& Cunningham, L. F. (2001). A cost/benefit approach to understanding service loyalty. Journal of services Marketing, 15(2), 113-130

Porter, M. 1998, Competitive Strategy: Techniques for Analyzing Industries and Competitors, The Free Press, New York, NY

Zeithaml, V. A. (2000). Service quality, profitability, and the economic worth of customers: what we know and what we need to learn. Journal of the academy of marketing science, $28(1), 67-85$

Retrieved from http://www.btrc.gov.bd/content/mobilephone-subscribers-bangladesh

Retrieved from http://www.btrc.gov.bd/telco/internet

Retrieved

from https://en.wikipedia.org/wiki/Telecommunications_in_Bang ladesh

$--0$ 
Online Archive: https://abc.us.org/ojs/index.php/abr/issue/archive

\section{S) Worldcat Google scholar $a b c G A T E$ Y BASE}

